\title{
New approach to the study of division of labour in the honeybee colony (Apis mellifera $L$ )
}

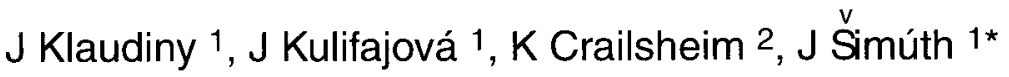 \\ 1 Laboratory for Genetic Engineering, Institute of Chemistry, Slovak Academy of Sciences, \\ Dúbravská cesta, 9, 84238 Bratislava, Slovakia; \\ 2 Karl-Franzens-Universität, Institut für Zoologie, Universitätsplatz, 2, A-8010 Graz, Austria
}

(Received 10 August 1994; accepted 9 September 1994)

\begin{abstract}
Summary - Using Northern analysis we determined differences in the transcription level of 4 mRNAs (coding for larval food proteins) in the heads of sister worker bees, which were either foragers or nurses rearing the larvae of workers, drones and queens. The ratio of the isolated total RNAs from the heads of these bee samples was estimated as 1:2:1.9:3.6, respectively.
\end{abstract}

Apis mellifera / division of labour / larval food / Northern analysis / mRNA / total RNA

\section{INTRODUCTION}

The age-related tasks in honeybee workers pass from cell cleaner to nurse, comb builder, food handler and guard to forager. This age polyethism has been correlated with changes in several physiological parameters (Rembold, 1974; Fluri et al, 1982; Seeley, 1985, Robinson et al, 1989), and proteolytic (Moritz and Crailsheim, 1987) and transcriptional activity (Severson et al, 1991).

However the possibility that nurse bees vary the protein composition of the food that they produce for worker, drone and queen larvae has not been tested. We present preliminary results on total RNA content and comparison of transcription levels of 4 mRNAs encoding honeybee larval food (HBLF) proteins in the heads of foragers and above-mentioned nurse bees.

\section{MATERIALS AND METHODS}

The honeybees were obtained from colonies (Styria, Austria) as follows. Apis mellifera carnica (Pollman) bees (aged 0-24 h) from 1 colony were marked and put into either a commercial queen-

\footnotetext{
${ }^{*}$ Correspondence and reprints
} 
right colony, a drone breeding colony (with a queen) or a queen breeding colony with 21 open queen cells (without a queen). From the first colony, we removed worker nurses (W) and foragers $(F)$, from the second, drone nurses (D), and from the third, queen nurses $(Q)$. The nurses were defined by their age ( $8 \mathrm{~d})$ and by their presence on or near the brood nest or the queen cells, respectively. Foragers were $27-31 \mathrm{~d}$ old and the foraging status was checked by observing pollen foraging or the presence of the bees on a food source at least $15 \mathrm{~m}$ from the hive. All bees were caught between late August (nurses) and the middle of September (foragers). They were immediately placed in liquid nitrogen.

Total RNAs from 22 heads of each of the above-mentioned honeybee sample were isolated according to the methods of Chomczynski and Sacchi (1987). Four cDNA probes encoding larval food proteins (designated as RJP57-1, RJP57-2, RJPX, and RJP54) were prepared from the clones obtained from the expression cDNA library of 8-day-old nurse honeybee heads (Klaudiny et al, 1994; Šimuth et al, unpublished results). For Northern analysis, total RNAs were electrophoresed in $1 \%$ agarose gel containing formaldehyde and transfered to GeneScreen membranes (NEN) (Sambrook et al, 1989). Blots were hybridized with [ $\left.{ }^{32} \mathrm{P}\right]$-labeled cDNA probes as described by Klaudiny et al $(1992,1994)$.

\section{RESULTS}

Differences in the content of total RNA in the heads of distinct nurses (W, D and $Q$ ) and of the foragers $(F)$ were found (table $I$ ). The transcription levels of 4 mRNAs coding for HBLF proteins were determined by Northern blot analysis of total RNA isolated from the heads of honeybee samples (W, $D, Q$ and $F$ ) employing their corresponding cDNAs as hybridization probes (fig 1). The mRNA-cDNA signals on the blots were quantified and the relative molar amounts (RMA) of analyzed mRNAs in heads of different honeybee samples were calculated (table I). The molar ratios of mRNAs were calculated relative to RJP57-2 mRNA for better comparison of transcription levels of studied mRNAs (table II).

\section{DISCUSSION}

In our previous studies, cDNAs from the heads of summer nurse honeybees from Slovakia and encoding HBLF proteins were

Table I. Relative amounts of total RNA and relative molar amounts (RMA) of mRNAs per head of forager $(F)$ and nurse bees $(W, D, Q)$ *.

\begin{tabular}{lccccr} 
Honey bees & $\begin{array}{c}\text { Relative amounts } \\
\text { of total RNA }\end{array}$ & \multicolumn{3}{c}{ mRNAs } \\
& RJP57-1 & RJP57-2 & RJPX & RJP54 \\
F & 1.0 & 3.8 & 1.0 & 26.7 & 76.8 \\
W & 2.0 & 29.6 & 7.8 & 106.7 & 116.7 \\
D & 1.9 & 38.7 & 9.7 & 168.9 & 221.5 \\
Q & 3.6 & 37.7 & 8.6 & 147.1 & 129.0
\end{tabular}

\footnotetext{
* The intensity of the signals of mRNA-CDNA hybrids on Northern blots were quantified by Phosphorlmager (Molecular Dynamics) using Program ImageQuan. Measured values were normalised to the same length (1000 bp) of CDNAs and divided by the calculated lowest value (RJP57-2 mRNA, foragers) to obtain RMA of mRNAs on the blots. These values were related to the amount of total RNA per head to determine RMA of studied mRNAs in 1 honeybee head.
} 


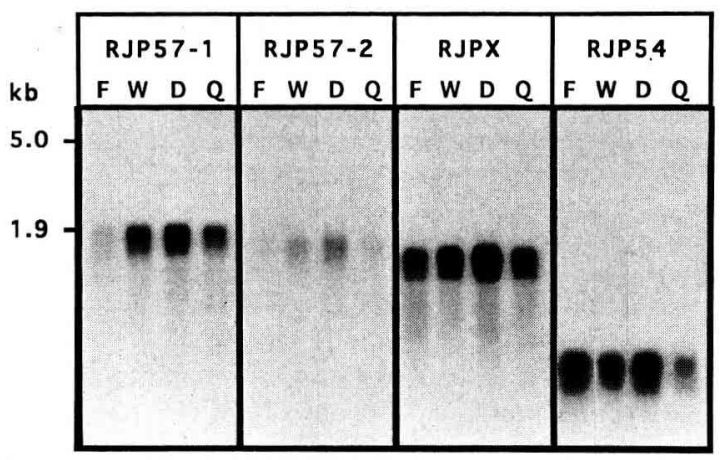

Fig 1. Northern blot analysis of 4 mRNAs in total RNA isolated from heads of forager $(F)$ and nurse bees (W, D and $Q$ ). Total RNAs, $0.6 \mu \mathrm{g}$ per lane, were loaded on the gel. The cDNAs encoding larval food proteins designated as RJP57-1, RJP57-2, RJPX and RJP54 were used as hybridization probes.

characterized (Klaudiny et al, 1994, Simúth et al, unpublished results).

In the current study, these cDNAs were used for Northern analysis of total RNAs isolated from the heads of foragers $(F)$ and nurses (W, D, Q) from Austria (fig 1).

Table II. Ratios of RMA of analysed mRNAs in heads of foragers $(F)$ and nurse bees ( W, D and Q) to RMA of RJP57-2 mRNA.

\begin{tabular}{lcccc} 
Honey & \multicolumn{5}{c}{ mRNAs } \\
bees & RJP57-1 & RJP57-2 & RJPX & RJP54 \\
& 3.8 & 1 & 26.7 & 76.8 \\
F & 3.8 & 1 & 13.9 & 15.1 \\
W & 4.1 & 1 & 17.8 & 23.3 \\
D & 4.3 & 1 & 16.9 & 14.8 \\
Q & & & &
\end{tabular}

From table $I$ it is evident that the transcription levels of tested mRNAs in total RNA of studied bees are markedly decreased in foragers compared to the nurse bees. The ratios of RMA of RJP57-1 and RJP57-2 mRNAs vary around the value 4 in all studied bee samples (table II), which correlates with the ratio determined for these mRNAs in honeybees from Slovakia (Klaudiny et al, 1994). This could be explained by the fact that these 2 mRNAs encode related proteins.

In the case of the other 2 mRNAs, however, the ratios of RMA of mRNAs were more variable between distinct honeybee samples (table II).

Pronounced differences between tested honeybee samples were found in the content of total RNAs in heads (ratio 1:2:1.9:3.6 for $F: W: D: Q)$. The differences between foragers and nurses in amounts of total RNAs and mRNAs (table 1) correlate with changes in proteosynthetic activity of hypopharyngeal glands during division of labour in workers (Haydak, 1970; Huang and Otis, 1989; Crailsheim, 1990; Knecht and Kaatz, 1990 ).

The interesting finding is that queen nurse has almost twice the amount of total RNA in their head as worker and drone nurses. This, together with some variability of transcriptional levels of the studied mRNAs in nurse samples, suggests that some differences in the production of HBLF proteins by nurses exist, which indicates a specialization in nurse honeybees. This conclusion needs further verification on a larger number of honeybee samples, comparison of individual variation within a sample, and inclusion of more mRNA species.

The results obtained in this work show that a methodological approach based on the determination of total RNA content and the transcriptional level of mRNAs in the honeybee can be useful to study division of labour in the honeybee colony. 


\section{ACKNOWLEDGMENTS}

We would like to thank Professor KH Scheit for enabling us to perform the major part of the experiments in his laboratory. We acknowledge the technical support of $\mathrm{K}$ Pfeiffer and a review of the manuscript by S Camazine.

Résumé - Nouvelle approche pour étudier la division du travail au sein de la colonie d'abeilles (Apis mellifera $\mathrm{L}$ ). Nous avons étudié la répartition de 4 ARN messagers (ARNm) (hybridation d'ADNc et d'ARNm), le codage des protéines de la nourriture larvaire, ainsi que la teneur totale en ARN des têtes de butineuses et de nourrices. Les abeilles analysées provenaient toutes de la même reine, avaient éclos en étuve et été introduites à l'âge de $1 \mathrm{j}$ dans diverses colonies. Un groupe de nourrices avait uniquement à s'occuper des larves d'ouvrières, un autre des larves de mâles et un $3^{e}$ des larves de reines. Les 3 groupes se sont distingués de celui des butineuses par la teneur totale en ARN de leur tête (respectivement de : $2,1,9$, $3,6,1)$. Outre le fait bien connu que les butineuses possèdent des glandes nourricières moins actives, ces résultats montrent une différence quantitative dans la capacité de synthèse protéique des nourrices en fonction du type de couvain dont elles s'occupent. La production moindre d'ARNm chez les butineuses par rapport aux nourrices varie en fonction de la protéine. Les méthodes appliquées dans cette étude préliminaire peuvent être très utiles pour étudier les différences individuelles et les différences d'origine génétique au sein d'un groupe de nourrices, ainsi que le système de division du travail dans son ensemble.

division du travail / nourriture larvaire / ARNm / total ARN / méthode Northern
Zusammenfassung - Ein neuer Ansatz zur Untersuchung der Arbeitsteilung im Bienenvolk (Apis mellifera $L$ ). Die Verteilungsmuster von 4 mRNA (cDNA-mRNAHybridisierung), die Futtersaftproteine codieren, sowie der Gesamt- RNA-Gehalt in Köpfen von Sammlerinnen und Ammenbienen wurde untersucht. Alle analysierten Bienen waren Nachkommen derselben Königin, waren im Brutschrank geschlüpft und am ersten Lebenstag in unterschiedliche Völker eingebracht worden. Es wurde je eine Probe von Ammenbienen, die ausschließlich Arbeiter-, Drohnen- oder Königinnenbrut zu versorgen hatten und Sammlerinnen untersucht. Die Gruppen unterschieden sich im RNA-Gesamtgehalt ihrer Köpfe wie: $2: 1.9: 3.6: 1$. Neben der bekannten Tatsache, daß Sammlerinnen weniger aktive Futtersaftdrüsen besitzen, weist dies auf einen quantitativen Unterschied der Proteinsynthese-Kapazität von Ammen hin, die verschiedene Brut zu pflegen hatten. Die Verminderung der mRNAProduktion der Sammlerinnen gegenüber den Ammen war nicht für alle Proteine gleich. Die in dieser Pilotstudie verwendeten Methoden können große Bedeutung in der Erforschung individueller und genetisch bedingter Unterschiede innerhalb der Gruppe der Ammen sowie des gesamten Arbeitsteilungssystems erlangen.

\section{Arbeitsteilung / Brutnährung / mRNA / gesamte RNA / Northern analysis}

\section{REFERENCES}

Chomczynski P, Sacchi N (1987) Single-step RNA isolation from cultured cells or tissues. Anal Biochem $162,156-259$

Crailsheim K (1990) The protein balance of the honey bee worker. Apidologie 21, 417-429

Fluri P, Lüscher M, Wille H, Gerig L (1982) Changes in weight of the pharyngeal gland and haemolymph titres of juvenile hormone, protein, and vitellogenin in worker honey bees. J Insect Physiol 28, 61-68 
Haydak MH (1970) Honey bee nutrition. Annu Rev Entomol 15, 143-156

Huang ZY, Otis GW (1989) Factors determining hypopharyngeal gland activity of worker honey bees (Apis mellifera L). Insectes Soc 36, 264-276

Klaudiny J, Kammer H von der, Scheit KH (1992) Characterization by cDNA cloning of the mRNA of a highly basic human protein homologous to the yeast ribosomal protein YŁ41. Biochem Biophys Res Commun $187,901-906$

Klaudiny J, Hanes J, Kulifajová J, Albert $\$$, Simúth J (1994) Molecular cloning of two cDNAs from the head of the nurse honey bee (Apis mellifera $L$ ) coding for related proteins of royal jelly. J Apic Res 33, 105-111

Knecht D, Kaatz HH (†990) Patterns of larval food production by hypopharyngeal glands in adult worker honey bees. Apidologie 21, 457-468
Moritz B, Crailsheim K (1987) Physiology of protein digestion in the midgut of the honeybee (Apis mellifera L). J Insect Physio/ 33, 923-931

Rembold H (1974) Die Kastenbildung bei der Honigbiene Apis mellifica $\mathrm{L}$ aus biochemischer Sicht. In: Sozialpolymorphismus bei der insekten (Schmidt $\mathrm{GH}$, ed) Wissenschaftliche Verlagsgesellschaft, Stuttgart, Germany, 350-403

Robinson GF, Page RE Jr, Strambi C, Strambi A (1989) Hormonal and genetic control of behavioral integration in honey bee colonies. Science 246, 109-111

Sambrook J, Fritsch EF, Maniatis T (1989) Molecular Cloning: A Laboratory Manual (2nd edition). Cold Spring Harbor Laboratory Press, New York, USA

Seeley TD (1985) Honeybee Ecology. Princeton University, NJ, USA

Severson, DW, Williamson, JL, Aiken, JM (1991) Aging and transcriptional activity in worker honey bees. Apidologie 22, 105-108 